\title{
Endodontics pastes formulated with copaiba oil: action on oral microbiota and dentin bridge formation in dogs
}

\author{
Pastas endodônticas formuladas com óleo de copaíba: ação na microbiota bucal e formação de \\ ponte dentinária em cães
}

\section{Fernanda Gosuen Gonçalves Dias ${ }^{I^{*}}$ Luciana Assirati Casemiro $^{\text {II }}$ Carlos Henrique Gomes Martins ${ }^{\mathrm{I}}$ Luis Gustavo Gosuen Gonçalves Dias ${ }^{\mathrm{III}}$ Lucas de Freitas Pereira ${ }^{\mathrm{I}}$ Lilian Toshiko Nishimura ${ }^{\mathrm{IV}}$ Fabiana Ferreira de Souza $^{v}$ Cristiane dos Santos Honsho ${ }^{\text {IV }}$}

\section{ABSTRACT}

This study analysed the effect of pastes formulated with calcium hydroxide P.A. and different vehicles (saline solution - paste $A$ and Copaifera langsdorffii Desfon oil - paste B) on oral microorganisms and dentin bridge formation in dogs. The antimicrobial action of the pastes and their components was analysed by the minimum inhibitory concentration in agar gel technique. The components were diluted and tested on fifteen standard strains of microorganisms associated with endodontic diseases. The microorganisms were cultivated and after incubation data was analysed using One-Way ANOVA and Turkey's test $(P \leq 0.05)$. Four superior incisors of ten animals were used to evaluate dentin bridge formation. Two incisors were capped with paste $A(G A)$ and two with paste $B(G B)$. After 90 days, the teeth were extracted for histological analysis and the degree of dentin bridge formation evaluated. Data was analysed by the Kruskal-Wallis test $(P<0.05)$. The pastes and their components were classified in the following decreasing order of antimicrobial action: calcium hydroxide P.A., paste A, paste $B$ and Copaifera langsdorffii Desfon oil. Calcium hydroxide P.A. showed significantly higher antimicrobial action than the pastes or their vehicles. No significant difference was observed between the two pastes in dentin bridge formation. Based on the microorganisms studied, it can be concluded that the pastes analysed showed similar antimicrobial potential but differed significantly from their individual components. No significant difference was observed in dentin bridge formation between the different pastes tested.

Key words: microbiology; dental pulp capping; medicinal plants.

RESUMO

Foi avaliada a ação de pastas formuladas com hidróxido de cálcio P.A. e diferentes veículos (solução fisiológica - pasta A e óleo de Copaifera langsdorffii Desfon-pasta B) sobre microrganismos bucais e formação de ponte dentinária em cães. A ação antimicrobiana das pastas e de seus componentes individuais foi avaliada pela técnica da concentração inibitória mínima pela diluição em ágar. Os materiais foram diluidos e avaliados contra quinze cepas padrão de microrganismos relacionados a doenças endodônticas. Os microrganismos foram cultivados e, após a incubação, os dados foram analisados (Anova OneWay, Tukey, $P \leq 0,05)$. Para a avaliação da formação de ponte dentinária, quatro incisivos superiores de dez animais foram tratados, sendo dois capeados com pasta $A$ (GA) e dois com a pasta $B(G B)$. Após 90 dias, os dentes foram extraídos para obtenção de cortes histológicos, com o objetivo de se avaliar o grau de formação de ponte dentinária. Os dados obtidos foram submetidos à análise estatística (Kruskal-Wallis, $P<0,05$ ). Segundo a ação antimicrobiana, os materiais foram classificados em ordem decrescente: hidróxido de cálcio P.A., pasta A, pasta $B$ e óleo de Copaifera langsdorffii Desfon, com diferenças estatisticamente significantes entre o hidróxido de cálcio P.A., as pastas e os veículos. Ao final do estudo, observou-se que as duas pastas avaliadas foram semelhantes quanto à formação de ponte dentinária. Considerando-se os microrganismos selecionados, conclui-se que as pastas avaliadas foram semelhantes entre si em termos de potencial antimicrobiano, diferindo dos componentes individuais. Em relação à formação de ponte dentinária, não foram observadas diferenças significantes entre os dentes tratados com as diferentes pastas.

Palavras-chave: microbiologia; capeamento da polpa dentária, plantas medicinais.

\section{INTRODUCTION}

Medicinal plants have been used in disease therapy for many years and the search for products of vegetal origin that could substitute conventional medicines in a more cost-effective

IPrograma de Pós-graduação em Ciências, Universidade de Franca (UNIFRAN), Rua Dr. Armando Salles de Oliveira, 201, 14404-600, Franca, SP, Brasil. E-mail: fernanda.dias@unifran.edu.br. *Corresponding author.

"Curso de Odontologia, UNIFRAN, Franca, SP, Brasil.

IIIDepartamento de Clínica e Cirurgia Veterinária, Universidade Estadual Paulista (UNESP), Jaboticabal, SP, Brasil.

${ }^{\text {IV }}$ Programa de Pós-graduação em Ciência Animal, UNIFRAN, Franca, SP, Brasil.

vDepartamento de Reprodução Animal, UNESP, Campus Botucatu, Botucatu, SP, Brasil. 
and aggressive manner has caught the interest of odontological researchers due to the high therapeutic potential of some vegetable molecules (ALVARES $\&$ JÚNIOR, 2009). The oil extracted from the stem of Copaifera langsdorffii Desfon (commonly known as copaíba) has attracted attention due to its various pharmacological properties and its antimicrobial and anti-inflammatory action (PIERI et al., 2012; MASSON et al., 2013; PIERI et al., 2014). It is believed that such therapeutic effects are related to the chemical structure of its components, such as the copalic acid and sesquiterpenes of the volatile fraction (MASSON et al., 2013; PIERI et al., 2014).

The therapeutic properties of Copaifera langsdorffii Desfon oil could be beneficial in odontological products such as intracanal pastes used for direct dental pulp capping as bacterial resistance. Their presence in inaccessible areas of the pulp canal may enable their presence even after rigorous endodontic chemical-mechanical preparation (ALVARES \& JUNIOR, 2009).

Calcium hydroxide P.A. $\left(\mathrm{Ca}(\mathrm{OH})_{2}\right)$ is successfully used in direct dental pulp capping as it stimulates pulp repair and isolates the tissue from aggressive agents through dentin bridge formation. This product is often associated with vehicles that favour its ionic dissociation or increase its antimicrobial effect, such as saline solution. However, the search for new vehicles is justifiable as these may significantly contribute to a favourable prognosis (GARCIA et al., 2009).

Considering the antimicrobial and antiinflammatory potential of Copaifera langsdorffii Desfon oil, the aim of this study was to analyse the effects of pastes formulated with calcium hydroxide P.A. and different vehicles, as well as the effects of their individual components against oral microorganisms associated with endodontic complications (Part 1). Furthermore, this study also aimed to evaluate the action of pastes $\mathrm{A}$ and $\mathrm{B}$ in dentin bridge formation in adult dogs following experimental dental pulp exposition (Part 2).

\section{MATERIAL AND METHODS}

Part 1 - Endodontic pastes and microbiological analysis

Two pastes were formulated for endodontic use. Paste A was composed of $3 \mathrm{~g}$ calcium hydroxide P.A. a added to $1.75 \mathrm{ml}$ sterile saline solution ${ }^{\mathrm{b}}$. Paste B was composed of $3 \mathrm{~g}$ calcium hydroxide P.A. added to $1.75 \mathrm{ml}$ Copaifera langsdorffii Desfon oil as vehicle ${ }^{\mathrm{c}}$ (GARCIA et al., 2009).
The antimicrobial activity of the endodontic pastes and their individual components, with the exception of the saline solution, was analysed on 15 standard human bacteria (American Type Culture Collection, ATCC, Manassas, VA, EUA) (Table 1) strains by the minimum inhibitory concentration (MIC) by dilution-agar technique, as recommended by the Clinical and Laboratory Standards Institute (CLSI, 2007 and 2009). Analysis was done in triplicate. The components tested were diluted in $50 \%$ glycerine solution, with the exception of the calcium hydroxide P.A., which was diluted in sterile distilled water. The final concentration of each component after dilution was $0.5 \%, 1 \%, 2 \%$ and $4 \%$.

Eighteen millilitres of BHIa (Brain Heart Infusion Ágar) and SCHa (Ágar Schaedler) culture media were supplemented with $5 \mathrm{mg} / \mathrm{ml}$ hemin and $1 \mathrm{mg} / \mathrm{ml}$ menadione and added to tubes containing $2 \mathrm{ml}$ of the different components at the various concentrations. The contents were poured into labelled Petri dishes and allowed to solidify. The inoculants were prepared in BHI broth (aerobic and microaerophilic microorganisms) or $\mathrm{SCHb}$ (anaerobic and facultative anaerobic microorganisms) after 24 or $72 \mathrm{~h}$ of culture, respectively. The suspensions were incubated for 24 or $72 \mathrm{~h}$, at $37^{\circ} \mathrm{C}$. Suspensions were standardized according to standard No. 0.5 of the McFarland scale, with the exception of the anaerobic bacteria and Candida albicans ATCC 18804, which were standardized by the turbidity of McFarland standard No. 1. The suspensions were placed into a Steers multi-applicator and the Petri dishes labelled based on the control $(0.12 \%$ chlorhexidine digluconate solution) and from the highest to the lowest dilution. Once the inoculants were dry the plates containing the aerobic and microaerophilic microorganisms were incubated for 24 and $48 \mathrm{~h}$, respectively. The plates containing anaerobic microorganisms were placed in a GasPack jar containing the anaerobiosis generator BBL GasPack Plus and incubated for $72 \mathrm{~h}$, at $36^{\circ} \mathrm{C}$, in an anaerobic chamber with atmosphere of $5-10 \%$ hydrogen, $10 \%$ carbon dioxide and $80-85 \%$ nitrogen. The MIC value of the endodontic toothpastes and their individual components was determined as the lowest concentration capable of completely inhibiting the development of previously established colonies of microorganism that commonly infect the dental pulp canal. The data obtained were analysed by One-Way ANOVA and Tukey's $(\mathrm{P} \leq 0.05)$.

Part 2 - Animals and experimental groups

Ten castrated male and female mixed breed adult dogs, from the Experimental Kennel 
Table 1 - Microorganism susceptibility to endodontic pastes and their individual components according to the minimal inhibitory concentration technique.

\begin{tabular}{|c|c|c|c|c|c|}
\hline \multirow{2}{*}{ Micro } & \multirow[b]{2}{*}{ Paste A } & \multirow[b]{2}{*}{ Paste B } & \multirow[b]{2}{*}{ Copaíba oil } & \multirow[b]{2}{*}{ Calcium hydroxide P.A. } & \multirow[b]{2}{*}{ Positive contro } \\
\hline & & & & & \\
\hline S. mutans ATCC 25175 & $2.0 \%$ & $\leq 0.5 \%$ & $2.0 \%$ & $\leq 0.5 \%$ & $\leq 0.5 \%$ \\
\hline S. mitis ATCC 49456 & $\leq 0.5 \%$ & $\leq 0.5 \%$ & $\leq 0.5 \%$ & $\leq 0.5 \%$ & $\leq 0.5 \%$ \\
\hline S. salivarius ATCC 25975 & $1.0 \%$ & $1.0 \%$ & $2.0 \%$ & $\leq 0.5 \%$ & $\leq 0.5 \%$ \\
\hline S. sanguinis ATCC 10556 & $1.0 \%$ & $1.0 \%$ & $1.0 \%$ & $\leq 0.5 \%$ & $\leq 0.5 \%$ \\
\hline S. aureus ATCC 6538 & $4.0 \%$ & $4.0 \%$ & $>4.0 \%$ & $1.0 \%$ & $\leq 0.5 \%$ \\
\hline E. faecalis ATCC 4082 & $2.0 \%$ & $2.0 \%$ & $>4.0 \%$ & $1.0 \%$ & $\leq 0.5 \%$ \\
\hline L. casei ATCC 11578 & $\leq 0.5 \%$ & $\leq 0.5 \%$ & $2.0 \%$ & $\leq 0.5 \%$ & $\leq 0.5 \%$ \\
\hline C. albicans AТCC 62342 & $\leq 0.5 \%$ & $\leq 0.5 \%$ & $2.0 \%$ & $\leq 0.5 \%$ & $\leq 0.5 \%$ \\
\hline P. aeruginosa ATCC 15442 & $1.0 \%$ & $1.0 \%$ & $>4.0 \%$ & $\leq 0.5 \%$ & $\leq 0.5 \%$ \\
\hline M. luteus AТCC 9341 & $1.0 \%$ & $1.0 \%$ & $>4.0 \%$ & $\leq 0.5 \%$ & $\leq 0.5 \%$ \\
\hline S. choleraesuis ATCC 10708 & $2.0 \%$ & $2.0 \%$ & $>4.0 \%$ & $\leq 0.5 \%$ & $\leq 0.5 \%$ \\
\hline $\begin{array}{l}\text { A.actinomycetem comitans } \\
\text { ATCC } 43717\end{array}$ & $\leq 0.5 \%$ & $=0.5 \%$ & $\leq 0.5 \%$ & $\leq 0.5 \%$ & $\leq 0.5 \%$ \\
\hline P. gingivalis ATCC 33277 & $\leq 0.5 \%$ & $=0.5 \%$ & $\leq 0.5 \%$ & $\leq 0.5 \%$ & $\leq 0.5 \%$ \\
\hline A.naeslundii ATCC 19039 & $\leq 0.5 \%$ & $4.0 \%$ & $4.0 \%$ & $\leq 0.5 \%$ & $\leq 0.5 \%$ \\
\hline P. nigrescens АТCС 33563 & $1.0 \%$ & $1.0 \%$ & $1.0 \%$ & $\leq 0.5 \%$ & $\leq 0.5 \%$ \\
\hline
\end{tabular}

of the Veterinary Hospital of the Universidade de Franca (UNIFRAN), Franca-SP, Brazil, were used to evaluate dentin bridge formation. Only animals showing absence of serious periodontal disease, dental wear and poor occlusion, intra or extra-oral fistulas or discoloured dental crown, absence of bone reabsorption, and ample size of the dental pulp canal were included in the study.

Two right (lateral and medial) and two left (lateral and medial) superior incisor teeth of each animal were analysed, totalling 40 teeth. The right incisor teeth were classified as Group A (GA, n=20) and capped with paste $A$. The left incisor teeth were classified as Group B (GB, n=20) and capped with paste B. In all groups the pastes were kept in direct contact with the experimentally exposed dental pulp. After dental pulp capping, the incisors were restored with reinforced zinc oxide and eugenol ${ }^{\mathrm{d}}$ cement to avoid dental pulp contact with the oral cavity. Once the cement was set, acid conditioning of the dental polish was carried out using $37 \%$ phosphoric acid gel ${ }^{\mathrm{e}}$. Subsequently, a small layer of cyanoacrylate gel ${ }^{\mathrm{f}}$ was applied over the restorations in order to improve their marginal seal and avoid potential microinfiltrations (CARVALHO et al., 2006). After the surgical procedure, animals received $11 \mathrm{mg} \mathrm{kg}^{-1}$ clindamycin ${ }^{\mathrm{g}}$ IM every 12 hours, for seven consecutive days, and $0.1 \mathrm{mg} \mathrm{kg}^{-1}$ meloxicam $^{\mathrm{h}}$ subcutaneous, every 24 hours, for four days.
Histological analysis

After 90 days of dental pulp capping, the superior incisors were removed, de-calcified with $4 \%$ nitric acid, immersed in paraffin and sectioned with a rotatory microtome. Histological slides were mounted and stained with Eosin-Haematoxylin. Light microscopy was used to evaluate the degree of dentin bridge deposition obliterating the experimentally exposed dental pulps and the following scores given: (1) absence of dentin bridge deposition; (2) discreet dentin deposition, (3) moderate dentin deposition and (4) intense dentin deposition, which was thick and uniformly distributed over the dental pulp. All histological samples were analysed by the same observer. The data obtained was analysed by the nonparametric test of Kruskal-Wallis and significance considered at $5 \%(\mathrm{P}<0.05)$.

\section{RESULTS}

The susceptibility of the microorganisms to the endodontic pastes and their individual components (calcium hydroxide P.A. and Copaifera langsdorffii Desfon resin oil) is detailed in table 1. Amongst the individual components analysed, the best results were obtained with calcium hydroxide P.A., with MIC values varying from $\leq 0.5 \%$ to $1.0 \%$. In the later concentration antimicrobial action could only be observed against $\boldsymbol{S}$. aureus and $\boldsymbol{E}$. faecalis. 
These results were significantly greater $(\mathrm{P} \leq 0.5)$ than those of the remaining components against the established microorganisms. Pastes A and B proved to be effective at the different concentrations tested (from $\leq 0.5 \%$ to $4 \%$ ), depending on the susceptibility of the microorganisms. The highest rates of microorganism development inhibition were obtained when both pastes, which acted against six standard strains, were diluted at $0.5 \%$. At $2 \%$ concentration, the antimicrobial action of paste A was superior to that of B, as it allowed the development of only one bacteria strain, which was successfully inhibited when the paste was used at $4 \%$ concentration. At this maximum concentration complete antimicrobial action was observed for both pastes.

The Copaifera langsdorffii Desfon oil acted against 3 bacteria strains when used at a concentration of $0.5 \%$. Up to $4 \%$ (maximum dilution tested in this study) no action could be observed against any 5 microorganisms. The antimicrobial action of the vegetable oil was similar or significantly inferior $(\mathrm{P} \leq 0.05)$ to that of the other components.

The positive control for the technique $(0.12 \%$ chlorexidine digluconate) showed the best results at inhibiting microorganism development, which were achieved when the lowest concentration of the product was used. These results were not compared to those obtained for the other components as the positive control was the control for the technique and not for the action of the components tested.

$S$. aureus was the most resistant microorganism to the materials analysed as its development was only inhibited by calcium hydroxide P.A. at $1 \%$ and by pastes $A$ and B at $4 \%$. Up to the maximum concentration tested, it was not possible to determine the MIC value of the vegetable oil for this bacterium. The most susceptible bacteria were $S$. mitis, A. actinomycetencomitans and $P$. gingivalis, which were inhibited by the materials used at a concentration $\leq 0.5 \%$.

According to these results and considering the lowest concentration tested, the materials were classified in decreasing order of antimicrobial action: calcium hydroxide P.A., paste A (aqueous vehicle), paste B (oil vehicle) and Copaifera langsdorffii Desfon oil. Data obtained for calcium hydroxide P.A. were significantly superior $(\mathrm{P} \leq 0.05)$ and those for vegetable oil significantly inferior $(\mathrm{P} \leq 0.05)$ to the data obtained for the other components.

The scores for dentin deposition on the exposed dental pulp of each treated tooth, of both experimental groups, are detailed in table 2. Both groups were able to promote the dentin bridge formation; however, GA showed superior results to GB, with $55 \%$ and $50 \%$ of teeth, respectively, receiving a score of 3 . Although the histological specimens presented different scores, by the end of the experiment, no significant difference $(\mathrm{P}=0.115)$ was observed between the materials tested in the different experimental groups.

\section{DISCUSSION}

In this study, Copaifera langsdorffii Desfon oil was chosen as a component for one of the pastes based on the reported antimicrobial and antiinflammatory properties of its plant of origin (PIERI et al., 2012; MASSON et al., 2013; PIERI et al., 2014). The antimicrobial activity of the different pastes up to the maximum concentration tested (compatible to its clinical application) was not significantly different. These findings are in disagreement with those of GOMES et al. (2002), who reported that materials using oil vehicles showed greater antimicrobial action than those formulated with aqueous or viscous vehicles.

Information on the antimicrobial action of Copaifera langsdorffii Desfon oil in natura is very limited (GOMES et al., 2002). In the present study, this oil showed effective antimicrobial activity against third of the microorganisms tested at MIC $\leq 0.5 \%$. However, comparison between the results obtained and the data available in the literature proved to be difficult due to the diversity of extracts and methodology reported in determining the antimicrobial potential of this material.

Table 2 - Frequency of superior incisors of dogs from groups A and $\mathrm{B}$, according to the scores of dentin deposition on experimentally exposed dental pulp.

\begin{tabular}{|c|c|c|c|c|}
\hline \multirow{2}{*}{ Groups } & \multicolumn{4}{|c|}{---------------Dentin deposition score----------- } \\
\hline & 1 & 2 & 3 & 4 \\
\hline $\begin{array}{l}\text { GA } \\
(n=20)\end{array}$ & $0(0 \%)$ & $0(0 \%)$ & $11(55 \%)$ & $9(45 \%)$ \\
\hline $\begin{array}{l}\text { GB } \\
(n=20)\end{array}$ & $0(0 \%)$ & $1(5 \%)$ & $10(50 \%)$ & $9(45 \%)$ \\
\hline
\end{tabular}

Established scores: 1) absence of dentin bridge deposition at the exposed pulp site; 2) discreet deposition; 3) moderate deposition in focal areas of pulp exposure; 4) intense dentin deposition, thick and uniform deposition over the pulp. $n=$ number of incisors analysed per group. 
BRAGA \& SILVA (2007), when using a similar technique to this study while analysing an aqueous extract of Copaifera langsdorffii Desfon at different concentrations $\left(0.05 \mathrm{~g} \mathrm{ml}^{-1} ; 0.1 \mathrm{~g} \mathrm{ml}^{-1}\right.$ and $0.2 \mathrm{~g} \mathrm{ml}^{-1}$ ), observed the complete inhibition of $\boldsymbol{S}$. aureus with material diluted at $0.2 \mathrm{~g} \mathrm{ml}^{-1}$. Even though the extracts are different, it was observed in this study that concentrations of up to $40 \mu \mathrm{g} / \mathrm{ml}$ of oil did not have a significant inhibitory effect on this bacterium.

It was also observed that calcium hydroxide P.A., even at the lowest concentration, was able to inhibit the development of the majority of the microorganisms tested, with the exception of $\boldsymbol{S}$. aureus and $\boldsymbol{E}$. faecalis, which were only inhibited at concentrations of and above $1 \%$. These data are in agreement with those reported by ESTRELA et al. (1997), who observed the action of this salt against M. luteus, $\boldsymbol{S}$. aureus and P. aeruginosa, which were also analysed in this study. GOMES et al. (2002) reported that calcium hydroxide P.A. pastes have greater antimicrobial action against gram-negative anaerobic bacteria than against gram-positive ones. The findings in this study are in agreement with the above statement, as A. actinomycetencomitans and $\boldsymbol{P}$. gingivalis were the microorganisms that showed the greatest susceptibility to both pastes, at MIC $\leq 0.5 \%$. E. faecalis is known for being highly resistant and associated with failures in endodontic treatment (GOMES et al., 2002). Furthermore, it has been known to survive in filled canals, in contrast to the results obtained in this study regarding its susceptibility to calcium hydroxide at $1 \%$.

The oil vehicles reduced the speed of calcium hydroxide P.A. dissociation due to their high molecular weight, thus reducing its efficacy as a direct capping agent (GOMES et al., 2002). However, in this study, the mechanism of action of this salt when added to the copaiba oil was not compromised as dentin bridge formation (in different intensity scores) could be seen in Group B while the vitality of the incisors' pulp remained unaffected.

Every endodontic medicine requires a minimum time in situ to produce the desired results. However, if kept for long periods it may cause damage to the dental tissues or may compromise the efficacy of the drug (ALVARES \& JÚNIOR, 2009). Thus, based on the study of GALA-GARCIA (2005), who reported denting bridge formation in dogs after 70 days of capping, the incisors in the present study were capped for 90 days.

Some considerations regarding to the methodology used in this study must be elucidated. Saline solution, which is widely used in odontology and enables the ionic dissociation of the calcium hydroxide P.A., was used in the comparative analysis of copaiba oil as a vehicle for endodontic pastes (ESTRELA et al., 1997). According to BRAGA \& SILVA (2007), the positive control for experiments analysing antimicrobial activity must be chosen from standard antimicrobials. Chlorexidine digluconate is considered the "golden standard" in odontology and it has been widely used in studies analysing odontological materials and thus has been chosen for this study.

The bacteria selected to analyse the antimicrobial properties of the calcium hydroxide pastes and their components were based on those found in the oral cavity and endodontic infections (ESTRELA et al., 1997). Taking into account that this study was developed in dogs, it is important to point out that there are great similarities between the canine and human oral microbiota (GOMES et al., 2002).

Cyanoacrylate gel was used to protect the surface of the temporary restorations in order to reduce marginal infiltration. Amongst the recommendation of this product in odontology and in agreement with the reports from CARVALHO et al. (2006), it was observed in this study that the waterproof seal on the tooth/restoration interface had a favourable effect on dental pulp restoration.

Dogs are considered ideal study models in human odontology due to their anatomic similarities and oral physiology, especially for the evaluation of dental materials biocompatibility (GALA-GARCIA, 2005). Thus, the results obtained in this study may aid and stimulate research in the area of human odontology using Copaifera langsdorffii Desfon oil or other products of vegetable origin.

\section{CONCLUSION}

Based on the microorganisms studied, it can be concluded that the pastes analysed showed similar antimicrobial potential but differed significantly from their individual components. No significant difference was observed in dentin bridge formation between the different pastes tested.

\section{SOURCES AND MANUFACTERS}

a - Biodinâmica Química e Farmacêutica Ltda, Ibiporã - PR, Brasil. b - Brasmédica S. A. Indústria Farmacêutica Ltda, São Paulo - SP, Brasil. c - lote 0790310, Apis Flora - Indústria e Comércio Ltda, Ribeirão Preto - SP, Brasil.

d - IRM - Dentsply Indústria e Comércio Ltda, Catanduva - SP, Brasil. 
e - Acid gel - Dentalville do Brasil Ltda, Joinville-SC, Brasil.

f - Loctite Super Bonder - Henkel - São Bernardo do Campo-SP, Brasil.

g - Clindacin - Cellofarm Farmacêutica Ltda, Rio de Janeiro - RJ. h - Bioflac - Cristália Produtos Farmacêuticos Ltda, Itapira - SP.

\section{BIOETHICS AND BIOSSE CURITY COMMITTEE}

The research in dogs was approved and overseen by the Ethical Committee for the Use of Animals from the Universidade de Franca (UNIFRAN), Franca, SP, Brazil (protocol n. 039/09).

\section{REFERENCES}

ALVARES, D.C.; JUNIOR, J.C.A. Endotoxina na endodontia. Revista Científica da UFPA, v.7, n.1, p.1-25, 2009. Available from: <http://www.ufpa.br/rcientifica/artigos_cientificos/ed_09/ pdf/rev_cie_ufpa_vol7_num1_cap5.pdf $>$. Acessed: Aug. 13, 2014 .

BRAGA, M.D.; SILVA, C.C.M. Atividade antimicrobiana do extrato aquoso de Copaifera langsdorffii Desf. sobre Staphylococcus aureus. Unimontes Científica, v.9, n.1, p.91-97, 2007. Available from: $<$ http://www.ruc.unimontes.br/index.php/ unicientifica/article/viewFile/381/207>. Accessed: Aug. 13, 2014.

CARVALHO, A.S. et al. Influência do cianoacrilato póstratamento endodôntico no selamento de restaurações de resina composta e de ionômero de vidro. Revista de Odontologia da Universidade Cidade de São Paulo, v.18, n.3, p.219-224, 2006. Available from: $<$ http://arquivos.cruzeirodosuleducacional.edu.br/ principal/old/revista_odontologia/pdf/setembro_dezembro_2006/ influencia_cianoacrilato.pdf>. Accessed: Aug. 13, 2014.

CLINICAL AND LABORATORY STANDARDS INSTITUTE. Methods for antimicrobial susceptibility testing of anaerobic bacteria, seventh edition: approved standard M11-A7. Wayne, PA, USA: CLSI; 2007. 47p.

CLINICAL AND LABORATORY STANDARDS INSTITUTE. Methods for dilution antimicrobial susceptibility tests for bacteria that grow aerobically; ninth edition: approved standard M07-A9. Wayne, PA, USA: CLSI; 2009. 63p.

ESTRELA, C. et al. Chemical study of calcium carbonate present in various calcium hydroxide samples. Brazilian Endodontics Journal, v.2, n.2, p.7-9, 1997

GALA-GARCIA, A. Avaliação antimicrobiana in vitro e da resposta do complexo dentino-pulpar in vivo após capeamento direto com Aloe vera L. em ratos. 2005. 128f. Dissertação (Mestrado em Odontologia) - Universidade Federal de Minas Gerais, Belo Horizonte MG.

GARCIA, L.F.R. et al. Antimicrobial activity of a calcium hydroxide and Ricinus communis oil paste against microorganisms commonly found in endodontic infections. Revista Odonto Ciência, v.24, n.4, p.406-409, 2009. Available from: <http:// revistaseletronicas.pucrs.br/ojs/index.php/fo/article/view/5337>. Accessed: Oct. 29, 2014.

GOMES, B.P. et al. Microbial susceptibility to calcium hydroxide pastes and their vehicles. Journal of Endodontics, v.28, n.11, p.758-761, 2002. Available from: <http://www.ncbi.nlm.nih.gov/ pubmed/12470019>. Accessed: Aug. 13, 2014.

MASSON, D.S. et al. Antimicrobial activity of copaíba (Copaifera langsdorffii) oleoresin on bacteria of clinical significance in cutaneous wounds. Revista Brasileira de Plantas Medicinais, v.15, n.4, p.664-669, 2013. Available from $<$ http://www.scielo. $\mathrm{br} / \mathrm{pdf} / \mathrm{rbpm} / \mathrm{v} 15 \mathrm{n} 4 \mathrm{~s} 1 / 06 . \mathrm{pdf}>$. Accessed: Oct. 29, 2014. doi. org/10.1590/S1516-05722013000500006.

PIERI, F. A. et al. Antimicrobial profile screening of two oils of Copaifera genus. Arquivo Brasileiro de Medicina Veterinária e Zootecnia, v.64, n.1, p.241-244, 2012. Available from: <http://www.scielo.br/pdf/abmvz/v64n1/ a37v64n1.pdf.>. Accessed: Oct. 29, 2014.doi.org/10.1590/ S0102-09352012000100037.

PIERI, F.A. et al. Antimicrobial activity of Copaifera langsdorffii oil and evaluation of its most bioactive fraction against bacteria of dog's dental plaque. Pakistan Veterinary Journal, v.34, n.2, p.165-169, 2014. Availiable from: <http://www.pvj.com.pk/pdffiles/34_2/165-169.pdf.>. Accessed: Oct. 29, 2014. 